\title{
Intracardiac thrombosis, phospholipid antibodies, and two-chambered right ventricle
}

\author{
MICHAEL A COPPOCK, ROBERT E SAFFORD, GORDON K DANIELSON \\ From the Division of Cardiovascular Diseases and Internal Medicine and the Section of Thoracic and \\ Cardiovascular Surgery, Mayo Clinic and Mayo Foundation, Rochester, Minnesota, USA
}

\begin{abstract}
SUMMARY A 34 year old woman with a history of five spontaneous abortions and a systemic lupuslike illness underwent cardiotomy for resection of a calcified right ventricular thrombus. At operation an anomalous right ventricular muscle bundle was discovered under the calcified thrombus. Clinical chemistry showed lupus anticoagulant activity and cardiolipin antibodies in the plasma.
\end{abstract}

Recently, better characterisation of phospholipid antibodies has led to renewed interest in the "lupus anticoagulant" and its clinical manifestations. We describe a patient who had a systemic lupus-like illness in which the "lupus anticoagulant" and cardiolipin antibodies were associated with intracardiac thrombosis.

\section{Case report}

A 34 year old woman with echocardiographic evidence of an intracardiac mass was referred to the Mayo Clinic. Her history included five spontaneous abortions occurring at 16 to 20 weeks of gestation. She had a poorly defined history of pretibial rash, arthralgias, joint swelling, and stiffness which were responsive to corticosteroids. Evaluation at another institution had showed an accelerated erythrocyte sedimentation rate but no antinuclear antibody or rheumatoid factor. There had been no definite additional symptoms, signs, or biochemical or immunological evidence of systemic lupus erythematosus, although she may have had a malar rash in the past. Three years previously, she had had episodic horizontal vertigo without other localising neurological symptoms. Shortly before coming to the Mayo Clinic she underwent echocardiographic evaluation elsewhere to exclude a cardiac source of emboli and for evaluation of a heart murmur. An intracardiac mass was found. There was no family history of systemic lupus erythematosus or lupus anticoagulant activity.

Requests for reprints to Dr Robert E Safford, Mayo Clinic Jacksonville, 4500 San Pablo Road, Jacksonville, FL32224, USA.
Examination at the Mayo Clinic showed an obese woman with a blood pressure of $142 / 100 \mathrm{~mm} \mathrm{Hg}$ and a regular heart rate of 85 beats $/ \mathrm{min}$. The lungs were clear. Her jugular venous pressure was not elevated, but she had prominent "a" and " $v$ " waves in her neck. Her carotid arteries had a normal upstroke but decreased volume. Her precordium was unremarkable. Auscultation revealed a normal $S_{1}$, a single $S_{2}$, a loud $S_{4}$, an early systolic sound, and a grade $3 / 6$ ejection murmur heard prominently at the base to the left of the sternum. The Valsalva manoeuvre and handgrip test reduced the intensity of the murmur.

The concentration of haemoglobin was increased $(155 \mathrm{~g} / \mathrm{l})$. Serum concentrations of cholesterol and triglyceride were normal. Serum protein electrophoresis showed a raised $\gamma$ globulin fraction (22.4 $\mathrm{g} / \mathrm{l})$. There were no monoclonal proteins in the urine or serum. The assay for antinuclear antibody was positive (1:640) and showed a mixed pattern. Total haemolytic complement was 15 units (normal, 25-70), C3 was $670 \mathrm{mg} / 1$ (normal, 880-2050), and C4 was $110 \mathrm{mg} / \mathrm{l}$ (normal, 1150-2680). The erythrocyte sedimentation rate was $24 \mathrm{~mm}$ in one hour. The test for rheumatoid factor was negative. She had a positive serological test (rapid plasma reagin) (1:4), but a negative specific test for syphilis (fluorescent treponemal antibody absorption). There were no antibodies to extractable nuclear antigens. There were IgG cardiolipin antibodies (1:16) but not IgM cardiolipin antibodies. ${ }^{1}$

Coagulation studies showed normal bleeding time (Ivy) and normal platelet count $\left(170000 / \mathrm{mm}^{3}\right)$. The prothrombin time was slightly prolonged and inhibited (23 seconds; normal 17-19). The plasma recalcification time with platelet rich plasma was 


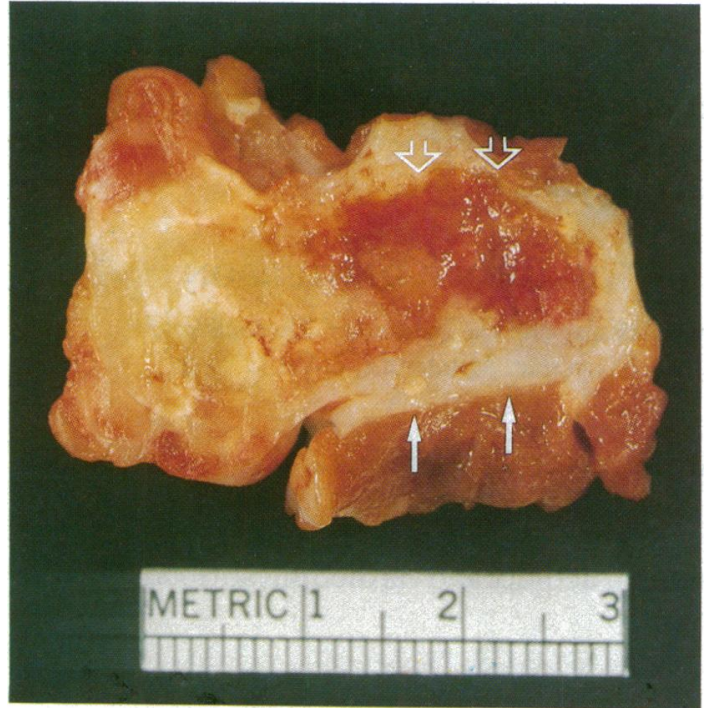

Fig 1 Specimen from right ventricle showing site of resected muscular diaphragm (below solid arrows), endocardial fibrosis and calcification (solid arrows), and thrombus (open arrows).

prolonged and inhibited in mixing tests with normal plasma (plasma clot time 149 seconds; normal 7090). The activated partial thromboplastin time was 95 seconds (normal 25-40) and was also inhibited in mixing tests. Specific clotting factors were not inhibited, and there was significant correction of the prolonged activated partial thromboplastin time in the platelet neutralisation procedure-a positive test. These findings are diagnostic of the lupus-like anticoagulant.

An electrocardiogram showed normal sinus rhythm and a $P$ wave with a vertical axis. An $x$ ray of the chest showed a prominent right atrium and right ventricle. A cross sectional echocardiogram showed dilatation of the right atrium and right ventricle and a calcified right ventricular mass attached near the papillary muscles of the tricuspid valve that extended into the right ventricular outflow tract. Doppler examination showed tricuspid insufficiency. Magnetic resonance imaging showed a $1.5 \times 2.5 \times 6.0 \mathrm{~cm}$ mass. Because of concern about the risk of thromboembolism, cardiac catheterisation was not performed.

The patient's constellation of symptoms, physical findings, and laboratory data resembled that of systemic lupus-like illness but did not satisfy the American Rheumatological Association's criteria for the classification of definite systemic lupus erythematosus. ${ }^{2}$

An operation was recommended. At right ven-

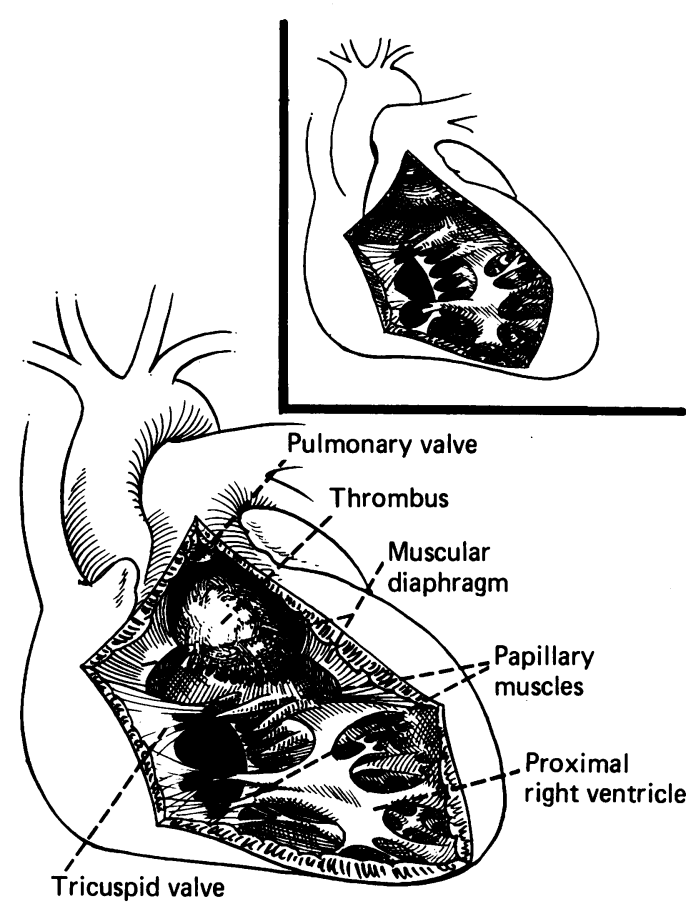

Fig 2 Drawing of operative view of right ventricular thrombus and anomalous muscle bundles. Inset, after resection.

triculotomy, inspection showed multiple muscle bundles dividing the inflow portion of the right ventricle from the outflow portion (as with a twochambered right ventricle). A large mass that was attached to this muscular diaphragm and protruded into the subpulmonary valve region was excised from the surrounding scar tissue (figs 1 and 2). The tricuspid valve apparatus was not affected. Histology showed partial organisation of necrotic thrombus, endocardial fibrosis, and focal fibroblastic proliferation; focal areas of fine calcific deposits; and focal clusters of chronic inflammatory cells (primarily lymphocytic, with focal accumulations of many eosinophils and plasma cells). Typical LibmanSachs vegetation was not seen.

The patient had an uneventful recovery after the operation. At discharge she was advised to continue warfarin treatment indefinitely, and she was considering a sterilisation operation.

\section{Discussion}

Systemic lupus erythematosus has long been recognised as being associated with in vitro anticoagulant activity. ${ }^{3}$ In 1963, Bowie and colleagues described 
four of eight patients who had lupus anticoagulant activity associated with thrombosis. ${ }^{4}$ The term "lupus anticoagulant" was coined by Feinstein and Rapaport in 1972,5 and much interest has been generated recently by the clinical expression of this syndrome. $^{6-12}$ The understanding of thrombosis associated with lupus anticoagulant activity has been further defined by the recognition of the role of cardiolipin antibodies in these phenomena. ${ }^{13-18}$

Cardiac manifestations of systemic lupus erythematosus and lupus-like illnesses are common. In 1924, Libman and Sacks reported valvar and mural endocarditis associated with systemic lupus erythematosus. ${ }^{19}$ Since their initial report, systemic lupus erythematosus has been shown to have protean cardiovascular manifestations. ${ }^{2021}$ These have included pancarditis with pericardial thickening and effusion, coronary artery disease with myocardial infarction, and, rarely, coronary arteritis. Reported valvar lesions have included Libman-Sacks endocarditis, valvar thickening, aortic insufficiency, mitral regurgitation, and infective endocarditis. Echocardiographic findings have included pericardial thickening, thickened aortic and mitral valves, and calcification of the mitral annulus.2 ${ }^{22}$ To our knowledge, an intracardiac mass in a patient with a lupus-like illness, lupus anticoagulant activity, and cardiolipin antibodies has not been reported before.

We did not find pericardial involvement or histological evidence of Libman-Sacks endocarditis in our patient. We saw no valve thickening at ventriculotomy. The normal peripheral eosinophil count and the appearance of the endocardium at operation excluded the hypereosinophilic syndrome.

Special coagulation features and clinical biochemical correlates of lupus anticoagulant activity and phospholipid antibodies were found in our patient, including prolonged phospholipid-dependent coagulation, inability to restore normal prothrombin time and activated partial thromboplastin time during mixing studies, a positive platelet neutralisation test, and raised titres to cardiolipin antibodies.

We speculate that an abnormal flow pattern in the right ventricle (caused by the anomalous muscle bundles), associated with a tendency to thrombosis because of the cardiolipin antibodies, led to the formation of the intracardiac mass in our patient.

Six months after operation the patient was symptom free. Although there are no data on the efficacy of long term anticoagulation in preventing recurrent thrombosis in this setting, the reports by Hughes $^{16}$ and Gastineau et $a l^{6}$ suggest that oral anticoagulation may be protective. In addition, Asherson et al have reported that warfarin withdrawal is associated with a high incidence of recurrent thrombosis. ${ }^{17}$ So we plan to treat the patient with warfarin anticoagulation indefinitely.

We thank Dr Henry A Homburger, for performing the assays for cardiolipin antibodies and Dr Harvinder S Luthra and Dr Francis J Kazmier for their advice on the paper.

\section{References}

1 Loizou S, McCrea JD, Rudge AC, Reynolds R, Boyle CC, Harris EN. Measurement of anti-cardiolipin antibodies by an enzyme-linked immunosorbent assay (ELISA): standardization and quantitation of results. Clin Exp Immunol 1985;62:738-45.

2 Tan EM, Cohen AS, Fries JF, et al. The 1982 revised criteria for the classification of systemic lupus erythematosus. Arthritis Rheum 1982;25:1271-7.

3 Conley CL, Hartmann RC. A hemorrhagic disorder caused by circulating anticoagulant in patients with disseminated lupus erythematosus [Abstract]. $\mathrm{J}$ Clin Invest 1952;31:621-2.

4 Bowie EJW, Thompson JH Jr, Pascuzzi CA, Owen CA Jr. Thrombosis in systemic lupus erythematosus despite circulating anticoagulants. J Lab Clin Med 1963;62:416-30.

5 Feinstein DI, Rapaport SI. Acquired inhibitors of blood coagulation. Prog Hemost Thromb 1972;1: 75-95.

6 Gastineau DA, Kazmier FJ, Nichols WL, Bowie EJW. Lupus anticoagulant: an analysis of the clinical and laboratory features of 219 cases. Am J Hematol 1985;19:265-75.

7 Mueh JR, Herbst KD, Rapaport SI. Thrombosis in patients with the lupus anticoagulant. Ann Intern Med 1980;92:156-9.

8 Branch DW, Scott JR, Kochenour NK, Herschgold E. Obstetric complications associated with the lupus anticoagulant. $N$ Engl J Med 1985;313:1322-6.

9 Gleicher N, Friberg J. IgM gammopathy and the lupus anticoagulant syndrome in habitual aborters. JAMA 1985;253:3278-81.

10 Lubbe WF, Butler WS, Liggins GC. The lupusanticoagulant: clinical and obstetric implications. NZ Med J 1984;97:398-402.

11 Boey ML, Colaco CB, Gharavi AE, Elkon KB, Loizou S, Hughes GRV. Thrombosis in systemic lupus erythematosus: striking association with the presence of circulating lupus anticoagulant. $\mathrm{Br} \mathrm{Med} \mathrm{J}$ 1983;287:1021-3.

12 Derksen RHWM, Kater L. Lupus anticoagulant: revival of an old phenomenon. Clin Exp Rheumatol 1985;3:349-57.

13 Lockshin MD, Druzin ML, Goel S, et al. Antibody to cardiolipin as a predictor of fetal distress or death in pregnant patients with systemic lupus erythematosus. N Engl J Med 1985;313:152-6.

14 Harris EN, Gharavi AE, Boey ML, et al. Anticardiolipin antibodies: detection by radioimmunoassay and association with thrombosis in systemic lupus erythematosus. Lancet 1983;ii:1211-4. 
15 Hughes GRV. The anticardiolipin syndrome. Clin Exp Rheumatol 1985;3:285-6.

16 Hughes GRV. Thrombosis, abortion, cerebral disease, and the lupus anticoagulant. $\mathrm{Br}$ Med $J$ 1983; 287:1088-9.

17 Asherson RA, Chan JKH, Harris EN, Gharavi AE, Hughes GRV. Anticardiolipin antibody, recurrent thrombosis, and warfarin withdrawal. Ann Rheum Dis 1985;44:823-5.

18 Harris EN, Chan JKH, Asherson RA, Aber VR, Gharavi AE, Hughes GRV. Thrombosis, recurrent fetal loss, and thrombocytopenia: predictive value of the anticardiolipin antibody test. Arch Intern Med
$1986 ; 146: 2153-6$.

19 Libman E, Sacks B. A hitherto undescribed form of valvular and mural endocarditis. Arch Intern Med 1924;33:701-37.

20 Chang RW. Cardiac manifestations of SLE. Clin Rheum Dis 1982;8:197-206.

21 Doherty NE, Siegel RJ. Cardiovascular manifestations of systemic lupus erythematosus. Am Heart J 1985;110:1257-65.

22 Klinkhoff AV, Thompson CR, Reid GD, Tomlinson CW. M-mode and two-dimensional echocardiographic abnormalities in systemic lupus erythematosus. JAMA 1985;253:3273-7.

\section{Notices}

\section{British Cardiac Society}

The Autumn Meeting will be held at the Wembley Conference Centre, London, on 22 to 24 November 1988. The closing date for receipt of abstracts was 24 June 1988.

The Annual General Meeting for 1989 will take place in Oxford on 6 and 7 April 1989, and the closing date for receipt of abstracts will be 6 January 1989 .

\section{Preventive cardiology}

The 2nd International Conference on Preventive Cardiology (sponsored by the Council on Epidemiology, American Heart Association) will take place in Washington, DC, on 18 to 22 June 1989. For details write to Secretariat, 9650 Rockville Pike, Bethesda, Maryland 20814, USA.

\section{Atrial arrhythmias}

An international symposium on Current Concepts in the Study and Management of Atrial Arrhythmias will be held in Lyon on 6 to 8 December 1989. For further information write to Professor P Touboul, Hôpital Cardiovasculaire et Pneumologique Louis Pradel, BP Lyon Montchat, 69394 Lyon Cedex 3, France.

\section{Electrocardiography}

A meeting on Electrocardiography: Past and Future will be held in Nice on 7 to 9 September 1989. For further information contact the Conference Department, The New York Academy of Sciences, 2 East 63rd Street, New York, NY 10021, USA.

\section{Diseases of the chest}

The 16th World Congress on Diseases of the Chest will be held at the Sheraton-Boston Hotel and Towers and the John B Hynes Convention Auditorium on 30 October to 3 November 1989. Information from Division of Education, American College of Chest Physicians, 911 Busse Highway, Park Ridge, IL 60068-2375, USA.

\section{British Nuclear Cardiology Group}

The annual meeting of the British Nuclear Cardiology Group will be held at the Robin Brook Centre, St Bartholomew's Hospital, West Smithfield, London EC1A 7BE on 21 November 1988. For further details contact $\mathrm{Dr}$ Richard Underwood, MR Unit, National Heart and Chest Hospitals, 30 Britten Street, London SW3 6NN (01-351 5773). 